\title{
Bamboo reinforced concrete: a critical review
}

\author{
Hector Archila $\cdot$ Sebastian Kaminski • David Trujillo $\cdot$ Edwin Zea Escamilla • \\ Kent A. Harries
}

Received: 20 January 2018/ Accepted: 16 July 2018/Published online: 19 July 2018

(C) The Author(s) 2018

\begin{abstract}
The use of small diameter whole-culm (bars) and/or split bamboo (a.k.a. splints or round strips) has often been proposed as an alternative to relatively expensive reinforcing steel in reinforced concrete. The motivation for such replacement is typically cost—bamboo is readily available in many tropical and sub-tropical locations, whereas steel reinforcement is relatively more expensive-and more recently, the drive to find more sustainable alternatives in the construction industry. This review addresses such 'bamboo-reinforced concrete' and assesses its structural and environmental performance as an alternative to steel reinforced concrete. A
\end{abstract}

H. Archila · K. A. Harries

University of Bath, Bath, UK

H. Archila

Amphibia BASE, Bath, UK

S. Kaminski

Arup, London, UK

D. Trujillo

Coventry University, Coventry, UK

E. Zea Escamilla

Head of Sustainable Building Research, Center for Corporate Responsibility and Sustainability, University of Zurich, Zurich, Switzerland

K. A. Harries ( $\square)$

University of Pittsburgh, Pittsburgh, USA

e-mail: kharries@pitt.edu prototype three bay portal frame, that would not be uncommon in regions of the world where bambooreinforced concrete may be considered, is used to illustrate bamboo reinforced concrete design and as a basis for a life cycle assessment of the same. The authors conclude that, although bamboo is a material with extraordinary mechanical properties, its use in bamboo-reinforced concrete is an ill-considered concept, having significant durability, strength and stiffness issues, and does not meet the environmentally friendly credentials often attributed to it.

Keywords Bamboo - Bamboo reinforcement . Bamboo-reinforced concrete $\cdot$ Concrete $\cdot$ Durability . Life cycle assessment

\section{Introduction}

The mechanical properties of bamboo and its availability in developing regions has led to its empirical use as reinforcement in concrete structures. The proposition of its widespread use as a sustainable alternative to steel in reinforced concrete structures, poses key questions to builders, engineers and researchers with regards to its structural capacity and compatibility, as well as constructability and sustainability issues. This paper discusses these issues, providing a holistic review of the literature in the field and a structural comparison between steel 
reinforcement and bamboo reinforcement in a typical concrete structure. The principle scope of this review is intentionally limited to the use of small diameter whole-culm (bars) and/or split (a.k.a. splints or round strips) bamboo. Recent advances in bamboo-composite materials may represent a viable bamboo-based concrete reinforcing product that will be only briefly discussed in this paper. Other applications of bambooderived materials in concrete structures such as bahareque construction, bamboo fibre reinforcement and bamboo ash admixtures are beyond the scope of this discussion.

Bamboo is frequently referred as a highly renewable and high-strength alternative material to timber and, occasionally as a 'strong-as-steel' reinforcement for concrete. The high rate of biomass production and renewability of sustainably managed bamboo plantations are undeniably key benefits of bamboo. Nonetheless, favourable comparison with steel, in terms of strength, is not valid. In a dry state, bamboo characteristic strengths are, at best, comparable to that of high-grade hardwood-between $30 \mathrm{MPa}$ (Oak) and $50 \mathrm{MPa}$ (American White Oak) [1]. Bamboo is a typically hollow, anisotropic, natural material with high variability of physical and mechanical properties across the section and along the culm. The density of bamboo varies through the cross section (from the inner culm wall to the outer), with typical values ranging from 500 to $800 \mathrm{~kg} / \mathrm{m}^{3}$. In longitudinal tension-dominated failure modes, bamboo typically exhibits a brittle behaviour. The variability of longitudinal mechanical properties of bamboo are similar to those of wood, having coefficients of variance between 10 and 30\% [2-4]. Due to the absence of radial fibres, however, bamboo is particularly weak in the direction perpendicular to the fibres, making it especially susceptible to longitudinal shear and transverse tension and compression failures. Steel, on the other hand, is a man-made, isotropic and ductile material having a density of $7800 \mathrm{~kg} / \mathrm{m}^{3}$ and a tensile yield strength of conventional reinforcing bars between 400 and $550 \mathrm{MPa}$. Additionally, steel is easily shaped to optimise its mechanical efficiency, requiring relatively little material to resist loads in a predictable manner. Such optimisation is not easily accomplished with bamboo without substantial processing, altering its properties and nature (e.g., Hebel et al. [5]). The oft-repeated claim that bamboo is 'the green steel' is founded in comparable-to-mild-steel values of strength and specific modulus. Some tests of small 'clear' (i.e., defect free) specimens of bamboo have reported ultimate tensile strengths on the order of $250 \mathrm{MPa}$ (e.g., Zhou et al. [6] and Lu et al. [7]). However, such results are not representative of the strength that can be mobilised in a full or partial culm: characteristic strength on the order of $40 \mathrm{MPa}$ and safe working stress for design on the order of $16 \mathrm{MPa}-$ similar to hardwood timber [1]. The tensile modulus of bamboo is on the order of $20 \mathrm{GPa}$ [8], about $10 \%$ of that of steel. The specific modulus - the ratio of elastic modulus per unit density-for bamboo in the longitudinal direction is approximately $25 \times 10^{6} \mathrm{~m}^{2} / \mathrm{s}^{2}$; a value comparable to both steel and Douglas Fir. However, unlike steel, the highly anisotropic nature of bamboo results in a specific modulus in the transverse or tangential directions barely a tenth of the longitudinal value; values comparable to nylon and polystyrene. Thus, the mechanical properties of bamboo and its appropriateness for structural applications are often misunderstood. On the other hand, when comparing embodied energy and $\mathrm{CO}_{2}$ footprint during manufacturing of bamboo and steel, a strong argument can be made in favour of bamboo. The embodied energy of medium carbon steel is about $29-35 \mathrm{MJ} / \mathrm{kg}$, while for bamboo culms this value is about 4-6 MJ/kg [9]. Similarly, the carbon footprint of steel is significantly greater than that of bamboo, with 2.2-2.8 $\mathrm{kgCO}_{2} / \mathrm{kg}$ (equivalent $\mathrm{kg}$ of $\mathrm{CO}_{2}$ per $\mathrm{kg}$ of material) for medium carbon steel [9] and $0.25 \mathrm{kgCO}_{2} / \mathrm{kg}$ for bamboo [10].

\section{Mechanics and behaviour of reinforced concrete}

Reinforced concrete is a composite material. Design of simple concrete cross sections is based on Bernoulli beam theory simultaneously satisfying conditions of equilibrium and strain compatibility. Equilibrium requires only knowledge of the concrete and reinforcing material constituent behaviours (modulus and strength). Strain compatibility requires bond between the concrete and reinforcing material to be maintained. Bond of non-prestressed reinforcing elements (bars) to concrete is primarily mechanical (through interlock with the surrounding concrete). Plain (undeformed) bars exhibit limited friction-induced bond. Any chemical bond between bar and concrete is rapidly 
overcome and not considered to contribute to bond capacity/behaviour.

\subsection{Strength}

In conventional steel-reinforced concrete design, members are designed to be 'under reinforced' such that the reinforcing steel yields prior to concrete crushing. This ensures a ductile member response by engaging the inherent ductility of the steel. This behaviour also results in an inherent overstrength or reserve capacity above the design requirement by permitting plastic behaviour and redistribution of internal stress to occur. Such behaviour allows multiple layers of steel reinforcement to be efficiently engaged. For a brittle reinforcing material such as bamboo or glass fibre reinforced polymer (GFRP), reinforcement failure is unacceptable (resulting in catastrophic failure of the member) and thus an 'overreinforced' design is prescribed by which limited ductility is achieved through concrete crushing [11]. In order to simultaneously satisfy equilibrium and strain compatibility requires providing a force in the reinforcing element, $T$, at a strain that is ultimately limited by concrete crushing strains. The force in the reinforcing element is typically given as the product of reinforcing bar area and stress in the bar, $T=A \times f$. While correct, this equation is more accurately written $T=A \times \varepsilon E$ where the stress in the bar is in fact, the product of bar strain $(\varepsilon)$ and modulus $(E)$. Therefore, to achieve comparable strength designs in steel and bamboo using only the nominal tensile capacity, considerably more bamboo area is required. The average tensile modulus of Guadua angustifolia bamboo is on the order $20 \mathrm{GPa}$ [8], resulting in a modular ratio $E_{\text {steel }} / E_{\text {bamboo }}=10$. Since the tension resisted by the reinforcing material is an issue of strength, a more conservative characteristic value $^{1}$ of tensile modulus falling between 7.5 and $13 \mathrm{GPa}$ at $12 \%$ moisture content should be used in design, resulting in a modular ratio as great as 27 [1]. Alternatively, larger strains may be developed to achieve a comparable bar force; this leads to considerations of serviceability: concrete crack control and member deflection. In addition, because bamboo is

\footnotetext{
${ }^{1}$ For bamboo culms, characteristic values are most often cited as the 5 th percentile value determined with $75 \%$ confidence [12].
}

brittle an elastic distribution of stresses must be adopted, therefore adding additional layers of bamboo reinforcement provides progressively less benefit as the stress level in each layer closer to the neutral axis is progressively less.

\subsection{Serviceability and minimum reinforcement}

Serviceability of concrete is typically considered in terms of member deflections and concrete crack control. Both are affected by the axial stiffness $(A E)$ of the reinforcing material. Assuming concrete is cracked (if it is not, it may be considered to be unreinforced), crack width, and therefore curvature and deflection, is a function of the axial stiffness of the reinforcing bar bridging the crack. Once again, bar area of a softer reinforcing material must be increased based on the modular ratio to achieve designs comparable to steel-reinforced concrete.

Minimum reinforcement is required for reinforced concrete members to ensure that they do not fail in a brittle manner immediately upon cracking. Conceptually, steel-reinforced concrete is designed to ensure that the nominal moment capacity exceeds $120 \%$ of the cracking capacity: $M_{n} \geq 1.2 M_{\text {cr }}$ (ACI 318-14). Additionally, minimum reinforcement is intended to provide crack control; that is, once a section is cracked, there is sufficient reinforcement to permit the development of additional cracks rather than all deformation being concentrated at a single initial crack. For steel-reinforced concrete, adequate crack control is achieved providing a reinforcing ratio of least $0.33 \%$ (ACI 318-14). Based on a typical nominal modular ratio (serviceability requirements will typically consider mean, rather than characteristic moduli), this implies requiring more than $3.5 \%$ bonded bamboo reinforcement to provide adequate crack control. Furthermore, this assumption assumes that the bond characteristics between reinforcing material and concrete are similar. If bond behaviour is poor or limited, considerably more bamboo reinforcing material is required.

It is informative to consider the case of GFRPreinforced concrete [11]. GFRP bars have a modular ratio $E_{\text {steel }} / E_{\mathrm{GFRP}}$ on the order of 5 . Design of such members is most often governed by serviceability considerations. Furthermore, to result in 'practical' designs, serviceability requirements for GFRP-reinforced concrete are often relaxed from those for steel- 
reinforced concrete. In particular, achieving acceptable crack control in GFRP-reinforced members often requires more reinforcement than is required for strength. These issues would be exacerbated using bamboo whose modular ratio is greater than 10 . In fact, crack control using bamboo may be even more inefficient since the modulus of the bamboo will typically be less than that of the surrounding concrete.

\subsection{Bond and development}

Integral to the foregoing discussion is the assumption of 'perfect bond' permitting force transfer between the reinforcing material and the surrounding concrete. To transfer force adequately, there must be a sufficient length of bar, known as the development length, over which the force is transferred from the concrete to the reinforcing bar. Bond force is developed by chemical adhesion, friction, and mechanical interlock between bar deformations and the surrounding concrete. Chemical adhesion is small, rapidly overcome and therefore neglected. The remaining components form a resultant stress that can be further broken into longitudinal (friction) and radial components. For deformed bars, mechanical interlock is the primary method of bond force transfer. For anisotropic materials, the radial component is reduced due to the greater compliance of the bar in the transverse direction. This may also lead to a second-order reduction in friction. If round bamboo or splints are used, there is little in the way of deformations to provide mechanical interlock. Thus, bond behaviour of bamboo reinforcement is anticipated to be more analogous to smooth bar than deformed bar development; relying mostly on friction to affect bond.

\section{Bamboo-reinforced concrete}

Published accounts indicate that the use of bamboo to reinforce concrete structures dates back a century in Southeast Asia. Early experimental studies of bamboo-reinforced concrete were conducted at MIT by Chow [13], in Germany [14], Italy [15], the United States [16], Smith and Saucier [17] and Colombia [18]. These studies used either bamboo bars (wholeculms of small diameter) or splints (semi-round strips).
Much early interest in bamboo-reinforced concrete is attributed to the US Navy and their interest in rapid [re-]construction in Southeast Asia following the Second World War. Research conducted by Glenn [16] on bamboo-reinforced concrete, financed by the US War Production Board, included mechanical tests and the construction of experimental buildings. Glenn produced a set of conclusions from the test results obtained, as well as design and construction principles for the use of bamboo canes and splints as reinforcement in concrete. Glen highlighted issues such as (a) high deflection, low ductility and early brittle failure of the bamboo reinforced concrete beams under load; (b) their reduced ultimate load capacity when compared to steel-reinforced elements; (c) bonding issues associated with excessive cracking and swelling of bamboo; and, (d) the need for using asphalt emulsions. Glenn advises use of a bamboo tensile stress of 34-41 MPa based on maximum stress values of 55-69 MPa for concrete beams with 3-4\% bamboo reinforcement. Finally, an allowable bamboo tensile stress between 20 and $28 \mathrm{MPa}$ for reinforced elements is recommended by Glenn in order to keep the deflection of the beam below 1/360 of the span.

Two later studies that report 'design methodologies' stand out. Brink and Rush [19] promulgate an allowable stress approach for designing bambooreinforced concrete comparable to the contemporary ACI 318 [20] approach for steel-reinforced concrete. Brink and Rush recommend an allowable bamboo tensile stress of $28 \mathrm{MPa}$ based on an ultimate capacity of $124 \mathrm{MPa}$ and a bond strength of $0.34 \mathrm{MPa}$. For serviceability requirements, they recommend a bamboo modulus of elasticity of $17.2 \mathrm{GPa}$.

Geymayer and Cox [21], on the other hand, recommend a hybrid design approach in which a bamboo-reinforced concrete flexural element is designed as an unreinforced concrete member with a maximum tensile stress of $0.67 \sqrt{ } f_{\mathrm{c}}^{\prime}$ (MPa units). To this, 3-4\% bamboo reinforcement is added resulting in, they claim, a factor of safety on the order of 2-2.5. A more refined analysis may be conducted using a recommended allowable bamboo stress of $34 \mathrm{MPa}$ and modulus of $13.8 \mathrm{GPa}$ for tension reinforcement and $8.6 \mathrm{GPa}$ for flexural reinforcement. Geymayer and Cox recognise the unique and limited bond behaviour of bamboo and recommend that bond strength be $44 \mathrm{~N} / \mathrm{mm}$ of reinforcing 'bar' circumference and that 
the embedment provided must exceed $305 \mathrm{~mm}$. This is a maximum bond stress of about $0.15 \mathrm{MPa}$. Geymayer and Cox based their study on Arundinaria tecta, a species of bamboo native to the Southeast United States.

Using either allowable stress-based approach, bond capacity will always control design. As a basis of comparison, a $25 \mathrm{~mm}$ diameter bamboo reinforcing bar embedded $305 \mathrm{~mm}$ can develop only between $3.5 \mathrm{kN} \mathrm{[21]} \mathrm{and} 8.4 \mathrm{kN}$ [19]. By contrast, a $9.5 \mathrm{~mm}$ diameter steel reinforcing bar in the same conditions can develop $29.4 \mathrm{kN}$.

A number of research papers describing bambooreinforced flexural members confirm the basic premise of the design methodology proposed by Geymayer and Cox [21]. Optimal ratios of longitudinal bamboo reinforcement range from 3 to $5 \%$ from which the capacity of an otherwise unreinforced concrete beam is increased at least 2.5 times [22-27]. It is recommended that design capacity be limited to the unreinforced section cracking moment, $M_{\mathrm{cr}}$, which, for a bamboo-reinforced section, should lead to a 'factor of safety' against cracking of 2 and against failure of 7 [23]. Although specific investigation of bond was not included in these studies, recommendations for the use of bamboo splint reinforcement include the requirement for two coats of bituminous paint with sand broadcast onto the top coat [23]. This is a procedure similar to that applied to bamboo splints by Ghavami [28], in which the author roughened the surface of bamboo before applying an initial coat of bituminous paint with sand and subsequently wrapped a $1.5 \mathrm{~mm}$ wire around the splints before applying a second coat.

In unrelated studies, Ghavami [29], Agarwal et al. [30] and Sevalia et al. [31] demonstrate the importance of providing at least minimum bamboo reinforcement and appropriate surface treatment to enhance bond. Ghavami [29] found that beams with a 3\% ratio of split bamboo reinforcement had four times the ultimate capacity of comparable unreinforced concrete beams. In the latter two studies, the authors report that bamboo-reinforced concrete with splints having no bond enhancement and a reinforcing ratio of approximately $1.4 \%$, offer no improvement over the behaviour of unreinforced concrete. Similarly, bamboo-reinforced slabs having a reinforcement ratio of only $0.5 \%$ developed a single large crack and exhibited significant reinforcement slip [32].
Two studies, Terai and Minami [33] and Leelatanon et al. [34], considered bamboo reinforcement for axial compression carrying members. These studies tested concentrically loaded column stubs having height to breadth ratios of 2 and 2.5, respectively. As should be expected from such short specimens, axial capacity may be approximated using transformed sections analysis and is improved in the presence of transverse confinement. No distinct difference between steel or bamboo-reinforced behaviour was evident in either experimental programme. Due to the short test specimen geometry, these tests have no reliance on bond to the concrete.

Ghavami [29] carried out an exploratory study on $2 \mathrm{~m}$ high concrete columns having $200 \mathrm{~mm}$ square cross-sections. These were reinforced with longitudinally-oriented bamboo splints having bond-enhancing surface treatment and were confined with steel stirrups. Ghavami remarks that $3 \%$ bamboo reinforcement in concrete columns was an ideal ratio to comply with Brazilian building regulations, but does not provide any values of ultimate strength or further details.

\subsection{Bond and development}

Agarwal et al. [30] showed the significant beneficial effects of 'treating' bamboo splints with commercial epoxy-based adhesives in order to enhance bond. They reported average bond stresses (from pull-out tests) on the order of $0.13 \mathrm{MPa}$ for plain bamboo splints (a value echoing the recommendation of Geymayer and Cox [21]) and values as high as $0.59 \mathrm{MPa}(350 \%$ increase) when Sikadur 32 adhesive was used to coat the splints. This behaviour translated to improved flexural response. Similarly, Ghavami [28] reports a $430 \%$ increase in the value of bond strength for Sikadur 32-coated bamboo splints embedded in concrete, when compared to uncoated splints; bond strength values were: 2.75 and $0.52 \mathrm{MPa}$, respectively. Ghavami also conducted tests with an asphalt (Negrolin) and sand coat which resulted in a bond strength of $0.73 \mathrm{MPa}$ (Fig. 1). Agarawal et al. report that a bamboo reinforcing ratio of $8 \%$ was necessary to result in flexural behaviour similar to that of a steelreinforced concrete member having a reinforcing ratio $0.89 \%$ (with a reported modular ratio, $E_{\text {steel }} / E_{\text {bamboo- }}$ $=8.3$ ). Bamboo splint reinforcement coated in Sikadur 32 required a reinforcing ratio of only $1.4 \%$ 
Fig. 1 Variation of bond stress with embedded length and the effects of surface treatment

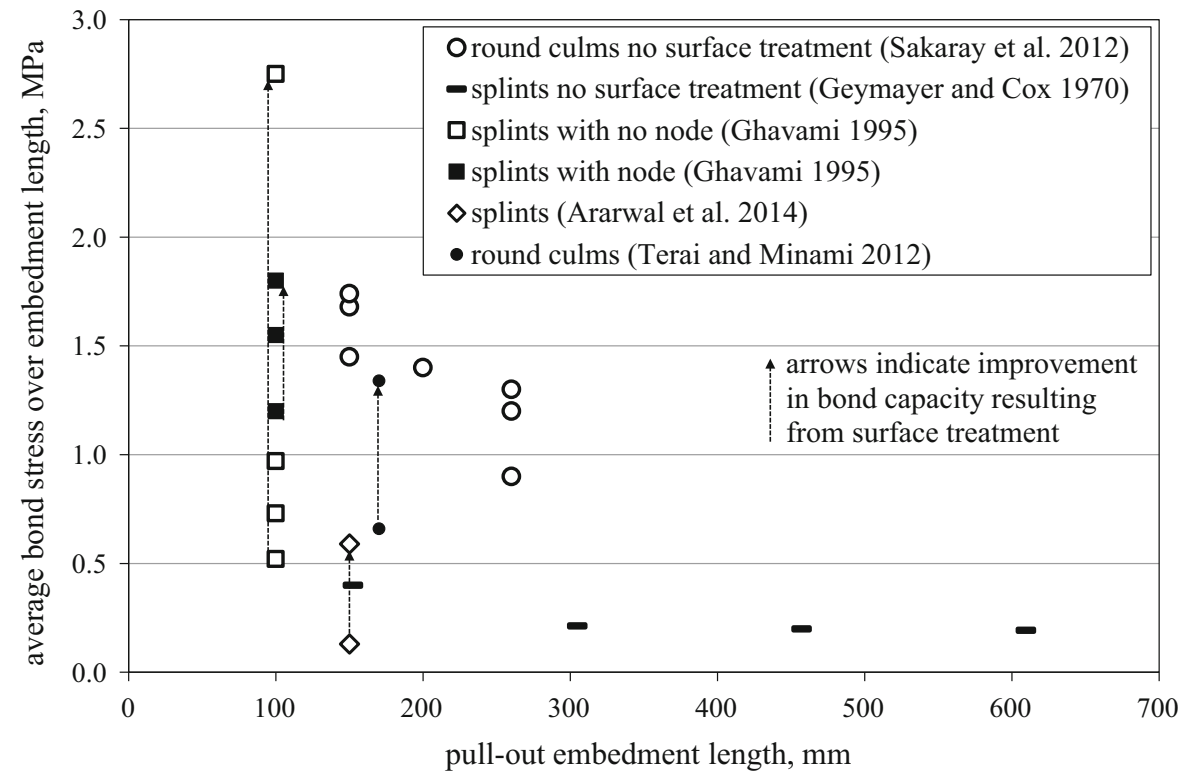

to achieve behaviour similar to that steel; implying a $470 \%$ improvement in behaviour when the splints were coated.

Terai and Minami [32] report pull-out bond tests of round bamboo samples having a variety of synthetic resin and synthetic rubber surface treatments. Untreated bond stress capacity is reported to be $0.66 \mathrm{MPa}$ and treatments increased this to values ranging up to $1.34 \mathrm{MPa}$. In the same test program, the bond capacity of deformed steel bar was reported as $2.43 \mathrm{MPa}$.

More realistically, Geymayer and Cox [21] and Sakaray et al. [35] report pull-out bond tests of splints and round culms, respectively, having varying embedment lengths. Both studies conclude that the average bond stress decreases as the embedment length increases, and that this decrease is significantly more pronounced than is observed in [isotropic] steel reinforcing bars. Such a reduction can be explained by the greater effects of shear lag and the poor transverse material characteristics of the anisotropic bamboo. As seen in Fig. 1, bamboo splints, which have no pronounced deformations (thus relying mostly on friction to transfer stress), exhibit a lower bond stress than round culms for which the nodal protrusions provide some degree of mechanical interlock. Geymayer and Cox concluded that bamboo splints had an effective bond length, beyond which further increases in embedded length had no effect on available capacity; from this they established their recommendation that bond strength be $44 \mathrm{~N} / \mathrm{mm}$ of reinforcing 'bar' circumference and that the embedment provided must exceed $305 \mathrm{~mm}$.

The presence of silica $\left(\mathrm{SiO}_{2}\right)$ in bamboo could contribute to a pozzolanic reaction, increasing the amount of calcium silicate hydrates (CSH) through reaction with $\mathrm{Ca}(\mathrm{OH})_{2}$ during hydration of Portland cement, that improves binding with concrete. However, the silica in bamboo occurs primarily in the epidermis (in a cellular level) and must be exposed to the concrete for the pozzolanic reaction to take place [36]. Therefore, when using bamboo in the form of culms or splints, additional pozzolanic activity is doubtful and is unlikely to contribute in any meaningful way to bamboo-concrete bond.

All known studies that address bond of bamboo in concrete identify shrinkage of untreated, green or presoaked bamboo, and swelling cycles resulting from variations in moisture in the concrete as being detrimental to bond. As a result, most studies recommend coating the bamboo in a moisture barrier, provided the coating does not result in a lubricating effect thereby, itself degrading the bond. On the other hand, sealing inadequately seasoned bamboo into a watertight environment has the potential to exacerbate decay. Finally, in practice, it is difficult to achieve a reliable and durable condition of water tightness. 
A common practice is to coat the bamboo in an epoxy or polyester resin and broadcast sand onto this to enhance bond characteristics; however, due to bamboo's hygroscopic nature, variations in bamboo moisture content (MC), and relative humidity $(\mathrm{RH})$, swelling or contraction of the material depending on moisture absorption and loss can occur. This can lead to labour and energy intensive, and potentially expensive treatments that defeat the purpose of using an inexpensive and locally available material. For example, Javadian et al. [37] report a maximum bond strength comparable to that of steel reinforcing bars, 3.65 MPa, for highly processed composite bamboo splints. To achieve this high bond stress, the splits were dried below $10 \%$ moisture content, heat-treated under pressure (to increase the density of bamboo) and coated using a water-based epoxy and fine sand.

Overall, research into cementitious and polymeric composites using bamboo and other natural materials as reinforcement, highlight common issues such as biodegradability, manufacturability and thermal compatibility of the bamboo and matrix material $[29,38]$. A final issue potentially affecting bond performance of bamboo is the coefficient of thermal expansion (CTE) which is a) affected by moisture content; and b) is as much as five times less than that of concrete or steel in the longitudinal direction, but two times greater than this value in the transverse direction. The reported CTE in the longitudinal direction for bamboo ranges between 2.5 and $10 \times 10^{-6} / \mathrm{C}$; transverse CTE is approximately an order of magnitude greater [9].

\subsection{Durability of bamboo reinforcement in concrete}

Durability of bamboo is closely related to its natural composition. As with other lignocellulosic materials, bamboo consists of cellulose, hemicellulose and lignin. The chemistry of these components in bamboo changes with age (e.g., when the plants reaches its mature state) and/or after harvesting, which triggers a process of cell death and tissue decay. Significant statistical correlation between changes in chemical composition, age and density in Phyllostachys pubescens and Gigantochloa scortechinii have been reported by $\mathrm{Li}$ et al. [39] and Hisham et al. [40], respectively.

There are few known studies specifically addressing the durability of bamboo embedded in concrete.
Nonetheless, there is considerable literature addressing the durability and treatment of different biomass materials (occasionally including bamboo) in cementitious materials. Gram [41] represents perhaps the first significant study in this regard and Vo and Navard [42] and Pacheco-Torgal and Jalali [43] provide recent and very thorough reviews. Most extant studies focus on 'fibre-reinforcement' or the inclusion of pulp materials in a cementitious composite. In this review, the authors have addressed only those durability issues believed to be relevant to bamboo-reinforced concrete. Readers are directed to the review articles noted for a discussion of other related durability issues.

Portland cement concrete is a highly alkali environment. The $\mathrm{pH}$ of pore water in Portland cement concrete typically exceeds 12 . This provides a passivating environment for embedded steel reinforcement-effectively mitigating the potential for steel corrosion provided the $\mathrm{pH}$ remains higher than 10 [44]. In contrast, alkali treatments are often used to break-down the cell structure of lignocellulosic materials such as wood, hemp, flax and bamboo [45] in order to retrieve, expose or treat their fibres. Such treatment may improve surface roughness (so called fibre sizing) to improve bond with polymeric resins in composite materials but are clearly undesirable in the case of bamboo bars used in bamboo-reinforced concrete. Hosoda [46] reports a 50\% loss of bamboo tensile capacity following 1-year conditioning in a high alkali water bath; after 3 years, the bamboo retained only $30 \%$ of its initial strength. Hemicellulose and water soluble extractives (the latter should generally not be present in treated bamboo culms) are reactive with calcium hydroxide $\left(\mathrm{Ca}(\mathrm{OH})_{2}\right)$ present in cement paste [47-50] leading to crystallisation of lime in the biomass pores [43]. Lignin is soluble in hot alkali environments [41] as is the case during cement hydration, and potentially when the concrete is exposed to direct sunlight in a tropical environment. Reducing alkalinity whether using ternary cements [51] or through carbonation [52] were found to only partially mitigate the degradation of biomass. Lignocellulosic materials in hydrated cement are also embrittled by mineralisation associated with cations (primarily $\mathrm{Ca}^{2+}$ ) in the concrete pore water [53].

Water absorption is a critical durability concern for biomass of any kind embedded in a cementitious matrix [43]. Water absorption and hygrothermal cycling result in essentially continuous volumetric 
change of the embedded biomass leading to interfacial damage and micro- and macro-cracking. These effects increase permeability, driving the deleterious processes described previously.

Biological attack is arguably the most critical concern for bamboo. When compared to wood there are certain factors that make bamboo more prone to decay, including: (a) its thin-walled geometry (making decay more significant in terms of reduction in member capacity), (b) its high starch content, and (c) the absence of decay-resistant compounds such as those found in some hardwood species such as Teak and Ipe $[3,54,55]$. There are two causes of biological decay in bamboo: insect (such as beetles and termites) and fungal attack (rot). Like timber [3, 56], four measures are required to protect bamboo from insect and fungal attack: (a) season the bamboo; (b) treat the entire through-thickness with chemicals; (c) keep bamboo dry and able to 'breath' throughout its life; and, (d) keep bamboo out of reach of termites.

Embedment in concrete is not believed to be sufficient to protect bamboo from insect-especially termite-attack. Termites can pass into cracks as small as $0.8 \mathrm{~mm}$ [57]. Bamboo-reinforced concrete is likely to exhibit such cracks from temperature, shrinkage and/or load effects. Thus, bamboo reinforcement requires chemical treatment through its entire wall thickness to mitigate insect attack $[55,58]$.

Fungal attack (rot) requires aerobic conditions and a moisture content typically exceeding 20\% [59]. Bamboo that is fully or partially embedded in concrete is vulnerable to rot because concrete (or mortar) is porous and moisture is easily transported through capillary action [60] and through existing cracks. Additionally, embedment in concrete is likely to prevent moisture that is present as a result of ingress, from rapidly evaporating or dispersing resulting in an increment in the moisture content of the bamboo. Surface or 'paint-on' treatments are generally not considered to provide sufficient protection against rot in timber [3, 56, 59] or bamboo [61]. To the authors' knowledge no comprehensive tests have been conducted to specifically assess the likelihood of bamboo decay when completely embedded in concrete. Except in cases in which the concrete remains dry throughout its service life, decay is possible even when the bamboo is coated in a bituminous or epoxy coating.

The issues of bamboo reinforcement degradation are aggravated by the fact that such damage will remain unseen. For example, corrosion of steel reinforcement occurs over years or decades and results in expansion of the steel reinforcement, leading to cracking, staining and spalling of the cover concrete thereby providing a visual 'warning' before the corrosion has become a safety-critical issue. However, in some environments bamboo could decay rapidly and degrade without providing an indication of damage at the concrete surface.

\section{Example: three bay portal frame}

In order to illustrate bamboo-reinforced concrete and contrast this with steel-reinforced concrete the first storey of a three bay, two story portal frame prototype is considered (Fig. 2a). The frame is $2.5 \mathrm{~m}$ tall and each bay spans $4.3 \mathrm{~m}$. Such a frame would not be uncommon in regions of the world where bambooreinforced concrete may be considered (Fig. 2b). The details of the steel-reinforced concrete prototype are selected (Fig. 3) and its nominal (i.e., unfactored) gravity load carrying capacity determined post priori based on the provisions of ACI 318 [62]. The bambooreinforced alternative is designed for the same gravity load and frame dimensions. In this way, the frames are identical functional units- they carry the same nominal loads over the same spans. For the sake of example, it was assumed that the frame is located in a structure also having infilled walls, thus the frame considered is not required to carry lateral load.

The following assumptions were made:

1. Concrete compressive strength, $f_{c}^{\prime}=21 \mathrm{MPa}$

2. Concrete modulus of rupture, $f_{r}=0.6 \sqrt{ } f_{c}^{\prime}=$ 2.75 MPa

3. Reinforcing steel yield strength, $f_{\mathrm{y}}=276 \mathrm{MPa}$ (such lower grade steel reinforcement is more typical in regions that may consider the use bamboo reinforced concrete)

4. Moments and shears were determined by ACI 318 $\$ 6.5$ simplified analysis; as a result, the critical section is negative flexure over the first interior support where the design moment is $0.1 w L^{2}$ and the design shear is $0.58 w L$, in which $w$ is the uniformly distributed gravity load and $L$ is the beam span.

5. $25 \mathrm{~mm}$ clear cover for all members. 

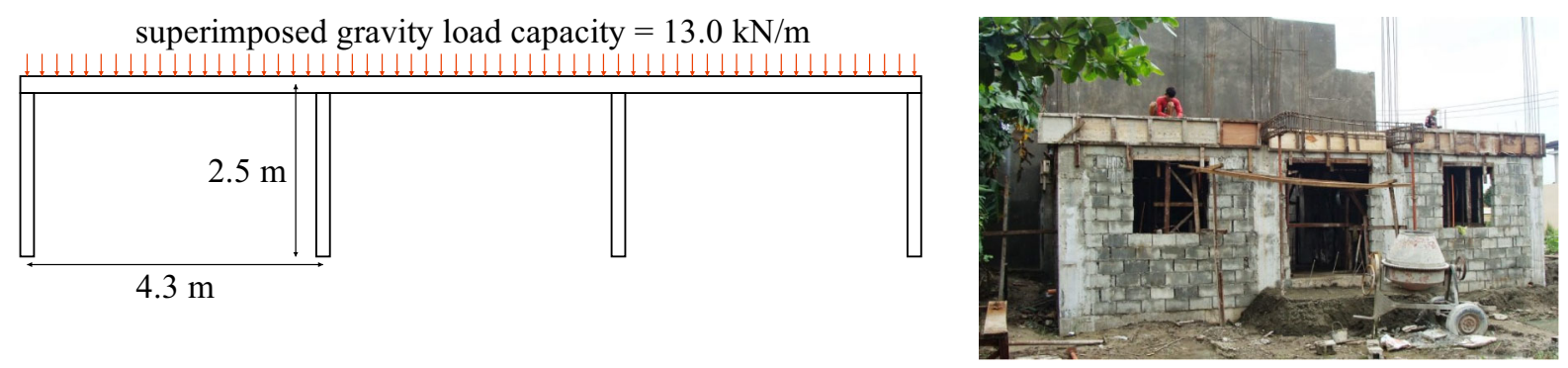

(a)

(b)

Fig. 2 Three bay concrete portal frame. a Prototype three bay portal frame geometry, b example of concrete portal frame construction in Philippines. Masonry infill is not load bearing. (photo: homebuildplan.com)

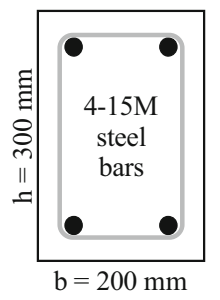

steel reinforced

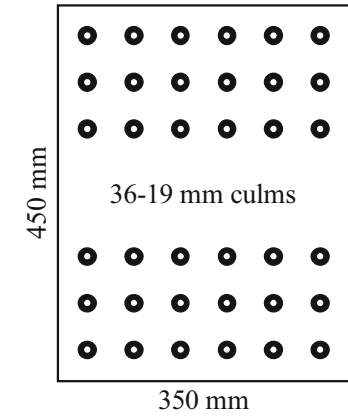

bamboo reinforced

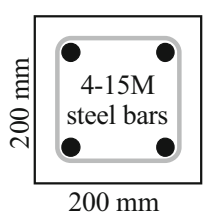

steel reinforced

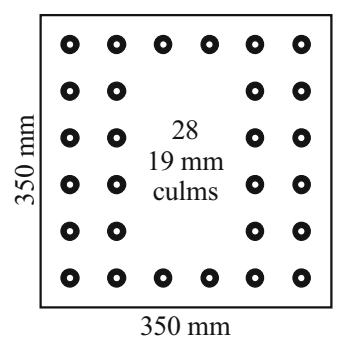

bamboo reinforced

(a)

(b)

Fig. 3 Three bay portal frame members. a Beam sections, b column sections

6. Centre-to-centre spacing of bamboo bars must be at least $3 \times$ culm diameter to permit adequate consolidation of concrete.

The beam section is $300 \times 200 \mathrm{~mm}$ (height $(h) \times$ width (b)) having $2-15 \mathrm{M}$ bars (area of single bar, $A_{\mathrm{b}}=200 \mathrm{~mm}^{2}$ ) top and bottom. The columns are $200 \mathrm{~mm}$ square having $4-15 \mathrm{M}$ bars. $10 \mathrm{M}$ $\left(A_{\mathrm{b}}=100 \mathrm{~mm}^{2}\right)$ transverse hoops spaced at $s=250 \mathrm{~mm}$ are provided in both the beam and column sections. Although both beams and columns are 'doubly reinforced', their moment capacity was assessed as though they were only singly reinforced. The depth to the primary tension reinforcement for the beam section is:

$$
d=300-25 \text { (cover) }-10(10 M \text { hoop })-15 / 2
$$

(centroid of primary bar) $=257 \mathrm{~mm}$.

The negative or positive moment capacity of the beam sections is determined as:

$$
\begin{aligned}
& M_{n}=A_{s} f_{y}\left(d-0.59 A_{s} f_{y} / b f_{\mathrm{c}}^{\prime}\right) \\
& M_{n}=2 \times 200 \times 276[257-(0.59 \times 2 \times 200 \times 276) / \\
& \quad(200 \times 21)]=26.6 \mathrm{kNm}
\end{aligned}
$$

The shear capacity of the beam section is:

$$
\begin{aligned}
V_{n}= & 0.16 \sqrt{ } f_{\mathrm{c}}^{\prime} b d+A_{v} f_{y} d / s \\
V_{n}= & 0.16 \sqrt{ } 21 \times 200 \times 257+2 \times 100 \times 276 \\
& \times 257 / 250=37.7+56.7=94.4 \mathrm{kN}
\end{aligned}
$$

From these capacities, the uniformly distributed gravity load capacity of the frame is found to be $w=14.4 \mathrm{kN} / \mathrm{m}$ as the lower of the following calculations of moment and shear.

$$
\begin{aligned}
M_{n} & =0.1 w L^{2} \rightarrow w=10 M_{n} / L^{2}=10 \times 26.6 / 4.3^{2} \\
& =14.4 \mathrm{kN} / \mathrm{m} \\
V_{n} & =0.58 w L \rightarrow w=V_{n} / 0.58 L=94.4 /(0.58 \times 4.3) \\
& =37.8 \mathrm{kN} / \mathrm{m}
\end{aligned}
$$


The self-weight of the beam $=1.4 \mathrm{kN} / \mathrm{m}$, resulting a nominal superimposed load carrying capacity of $13.0 \mathrm{kN} / \mathrm{m}$. The resulting moment and axial load demand on the exterior columns is determined by ACI $318 \S 6.5$ simplified analysis to be $16.6 \mathrm{kNm}$ and $31.0 \mathrm{kN}$, respectively, while that for the interior columns is $2.4 \mathrm{kNm}$ and $66.6 \mathrm{kN}$, respectively.

\subsection{Design by Geymayer and Cox [21]}

Applying the approach of Geymayer and Cox [21], the frame must be redesigned as being uncracked. The required section modulus of the beam, $S=b h^{2} / 6$, is determined from the assumed modulus of rupture:

$S_{\text {req }}=M_{n} / f_{r}=26.6 \times 10^{6} / 2.75=9,700,000 \mathrm{~mm}^{3}$

Minimising the beam area while providing sufficient beam width to place a large number of bamboo bars, results in a gross concrete beam dimension $h \times b=$ $450 \times 350 \mathrm{~mm}, 260 \%$ larger than the steel-reinforced beam. It is noted that to maintain the same superimposed load carrying capacity of $13.0 \mathrm{kN} / \mathrm{m}$, a larger section is required due to the increased girder selfweight $(3.7 \mathrm{kN} / \mathrm{m})$. Similarly, the required column dimensions are determined from:

$S_{\text {req }}=M_{n} / f_{r}=16.6 \times 10^{6} / 2.75=6,040,000 \mathrm{~mm}^{3}$

Maintaining the column width, $b=350 \mathrm{~mm}$ (to facilitate ease of formwork), requires a $350 \mathrm{~mm}$ square column, $300 \%$ larger than the steel-reinforced column.

Providing 3\% bamboo results in the beams requiring $4725 \mathrm{~mm}^{2}$ bamboo 'bars' top and bottom. Assuming $19 \mathrm{~mm}$ diameter culms having a wall thickness of $7 \mathrm{~mm}\left(A_{\mathrm{b}}=264 \mathrm{~mm}^{2}\right), 18$ such bars are required. Similarly, for the columns, 28 culms are required. A schematic comparison of the beam and column sections is shown in Fig. 3. Constructability issues may require even larger concrete cross sections to (a) ensure adequate spacing between adjacent bars to ensure concrete consolidation in such a congested section; and (b) eliminate interference between beam and column reinforcement. Additionally, although 3\% bamboo is provided, providing this in multiple layers of reinforcement is less efficient due to the strain gradient in the section. Reinforcement located closer to the neutral axis is less efficient and since bamboo does not yield as steel does, no redistribution between layers of reinforcement can occur. Thus, if multiple layers of reinforcement are required, it is likely that greater than $3 \%$ bamboo is required in order to achieve the desired behaviour implied by Geymayer and Cox [21]. This effect has not been considered in this intentionally simplified example. Finally, it is noted that the example considers nominal capacities. Design capacities are less that than these. It may be reasonably assumed that bamboo-reinforced concrete, being composed of two brittle materials, would require an increased 'safety factor' compared to steel-reinforced concrete which is ductile in nature. This would result in an even less efficient bamboo-reinforced concrete design.

It is unclear how to handle the shear reinforcement with bamboo. In this example, the shear reinforcement is minimal and could, perhaps, be also replaced with bamboo, although this is not considered in this example. If steel reinforcement were used, the spacing could be increased to $450 \mathrm{~mm}$ and $350 \mathrm{~mm}$ for the beams and columns, respectively.

\subsubsection{Development of bamboo bars}

Using this example, it is informative to investigate the development of the bamboo reinforcement. Geymayer and Cox [21] recommend a bamboo bond capacity of $44 \mathrm{~N} / \mathrm{mm}$ circumference; in this case $2.6 \mathrm{kN} / \mathrm{bar}$ (i.e. $44 \times 19 \times \pi$ ). The $3 \%$ bamboo reinforcement ratio is partially premised on ensuring that there is sufficient reinforcement to resist the tension force if a crack were to occur. It is therefore possible to estimate the tension capacity of the bar required as that corresponding to the bar tension occurring upon initial cracking, $T_{\text {req: }}$ :

$$
\begin{aligned}
M_{\mathrm{cr}} & =S f_{r}=1 / 6 \times 450^{2} \times 350 \times 10^{-6} \times 2.75 \\
& =32.5 \mathrm{kNm} \\
T_{\text {req }} & \approx M_{\mathrm{cr}} / 0.9 d=32.5 \times 10^{3} /(0.9 \times 415) \\
& =87 \mathrm{kN} \text { or } 4.8 \mathrm{kN} / \mathrm{bar}
\end{aligned}
$$

Thus the "equivalent" beam design (shown in Fig. 3) using bamboo having no bond-enhancing surface treatment is able to develop only $54 \%$ of the force present when the beam cracks. That is to say, if a moment sufficient to crack the beam occurred, the reinforcement would be unable to resist the tensile force-experiencing a bond failure-that would need 
to be transmitted across the crack and the beam would fail catastrophically as though it were not reinforced at all. In order to have sufficient tensile capacity at the cracking moment, assuming a $300 \mathrm{~mm}$ embedment length, an average bond stress of $0.27 \mathrm{MPa}$ is required for the $19 \mathrm{~mm}$ culm to achieve a capacity of $4.8 \mathrm{kN}$. [i.e.: $4800 /(300 \times \pi \times 19)$ ]. This level of bond stress is reported to be achievable using various surface treatments [30, 32].

Perhaps more significantly, the example is a statically indeterminate structure. Such structures rely on ductility imparted by reinforcing steel yielding to affect moment redistribution (implicit in used of ACI $318 \$ 6.5$ simplified analysis) and to attain adequate levels of safety should conditions different to those assumed in design occur. To accomplish these objectives, ACI 318-14 implicitly requires a reinforced concrete element to satisfy the basic ductility requirement $M_{n} \geq 1.2 M_{\text {cr. }}$. Thus, if the section does crack, there is sufficient reserve capacity in the reinforced section to mitigate catastrophic failure and to permit moment redistribution through steel yield. In the example presented here, unless significantly improved bond is provided, the behaviour is expected to be brittle with the bamboo not providing effective postcracking reinforcement. Such brittle behaviour is reported by Agarwal et al. [30], Sevalia et al. [31] and Terai and Minami [32]. Even in cases in which the $M_{n} \geq 1.2 M_{\text {cr }}$ is satisfied, there are no known studies demonstrating ductility or energy-absorbing capacity of bamboo-reinforced concrete. The expected brittle behaviour of bamboo-reinforced concrete indicates that it is inappropriate for use in indeterminate structures in which moment redistribution is assumed or permitted and in seismic environments.

\subsubsection{Summary of frame design quantities}

Table 1 summarises the comparable steel and bamboo reinforced concrete portal frame designs.

If a construction epoxy having an average coating thickness of $0.5 \mathrm{~mm}$ were used to enhance bond performance, $30 \mathrm{~cm}^{3} / \mathrm{m}$ of bamboo is required. For a single frame, this is $23 \mathrm{~L}$ without accounting for waste. A bituminous coating may require upwards of $50 \mathrm{~L}$ per frame. Both surface treatment methods come with additional monetary, labour and environmental costs.

\subsection{One-way slab spanning between adjacent portal frames}

A one-way simply-supported slab spanning $3 \mathrm{~m}$ between adjacent portal frames (from the previous example) is also designed. In simple concrete construction, slabs tend to be singly reinforced in which case they cannot be relied upon to develop continuous behaviour over supports. The steel reinforced concrete prototype slabs are $100 \mathrm{~mm}$ thick and primary reinforcement is $10 \mathrm{M}$ reinforcing bars spaced at $300 \mathrm{~mm}$. The moment and shear capacities of the slab are:

$$
\begin{aligned}
& M_{n}=A_{s} f_{y}\left(d-0.59 A_{s} f_{y} / b f_{\mathrm{c}}^{\prime}\right)=3.33 \times 100 \times 276 \\
& {[75-(0.59 \times 3.33 \times 100 \times 276) /(1000 \times 21)] } \\
&= 6.7 \mathrm{kNm} / \mathrm{m} \\
& V_{n}= 0.16 \sqrt{ } f_{\mathrm{c}}^{\prime} b d=0.16 \sqrt{ } 21 \times 1000 \times 75=55 \mathrm{kN} / \mathrm{m}
\end{aligned}
$$

The self-weight of the slab is $2.4 \mathrm{kN} / \mathrm{m}^{2}$. The nominal superimposed load that may be carried by the slab is $1.9 \mathrm{kN} / \mathrm{m}^{2}$ and is controlled by the load carrying capacity of the frame rather than the slab itself (superimposed load carrying capacity of slab itself is $3.6 \mathrm{kN} / \mathrm{m}^{2}$ ).

The cracking moment of the $100 \mathrm{~mm}$ slab is $4.6 \mathrm{kNm} / \mathrm{m}$, corresponding to a superimposed load capacity of $1.7 \mathrm{kN} / \mathrm{m}^{2}$. Therefore, based on the approach recommended by Geymayer and Cox [21], the equivalent bamboo-reinforced slab depth must be increased marginally to $110 \mathrm{~mm}$ in order to resist a superimposed load of $1.9 \mathrm{kN} / \mathrm{m}^{2}$ without cracking. The bamboo reinforcement requirement is $3300 \mathrm{~mm}^{2}$ / $\mathrm{m}$, equal to $19 \mathrm{~mm}$ culms $\left(A_{\mathrm{b}}=264 \mathrm{~mm}^{2}\right)$ on $80 \mathrm{~mm}$ centres.

Once again, using the bond capacity recommendations of Geymayer and Cox [21], the capacity provided without bond-enhancing surface treatment is only $43 \%$ of that required to resist the tension developed in the reinforcement upon cracking of the concrete, resulting in a brittle behaviour unaffected by the presence of the bamboo reinforcement. In order ensure that the bamboo reinforcement can resist tensile force at $M_{\text {cr }}$ an average bond stress over $300 \mathrm{~mm}$ of $0.34 \mathrm{MPa}$ is required; this value is reported to be achievable with appropriate surface treatment. 
Table 1 Material quantities for example portal frame

\begin{tabular}{lll}
\hline & Steel reinforced concrete & Bamboo reinforced concrete \\
\hline Functional unit & Three-bay portal frame having nominal superimposed gravity load capacity of 13.2 kN/m \\
$21 \mathrm{MPa}$ concrete & $1.2 \mathrm{~m}^{3}=2880 \mathrm{~kg}$ & $3.3 \mathrm{~m}^{3}=7920 \mathrm{~kg}$ \\
$276 \mathrm{MPa} 15 \mathrm{M}$ reinforcing steel & $92 \mathrm{~m}=145 \mathrm{~kg}$ & None \\
$276 \mathrm{MPa} 10 \mathrm{M}$ reinforcing steel & $\approx 84 \mathrm{~m}=66 \mathrm{~kg}$ & $\approx 86 \mathrm{~m}=68 \mathrm{~kg}$ (shear reinforcement) \\
$19 \mathrm{~mm}$ diameter bamboo bar & None & $744 \mathrm{~m} \approx 182 \mathrm{~kg}$ \\
Area of formwork required & $\approx 18.3 \mathrm{~m}^{2}$ & $\approx 30.1 \mathrm{~m}^{2}$ \\
\hline
\end{tabular}

\subsection{Constructability and other issues of concern}

The previous sections discussed a number of key issues regarding the design and performance of bamboo-reinforced concrete. However, there are other practical issues that also hinder its use in conventional construction. These include:

1. The weakness of bamboo perpendicular to the fibres makes hollow bars prone to crushing or splitting during transportation, handling and erection. Like GFRP bars (which are also highly anisotropic), bamboo bars must be handled with additional care not required for steel bars.

2. There is no known research addressing methods of splicing or the behaviour of splices in bamboo reinforcing bars. Like steel, bamboo bars are practically limited to about $6 \mathrm{~m}$ in length; thus splicing will be necessary in many structures.

3. There is no known research addressing the anchorage (beyond bond development) of bamboo in concrete. Whereas steel bars are easily bent and GFRP bars may be bent during their manufacture, it is not believed to be practical to bend bamboo bars in a manner appropriate to provide anchorage in concrete. Thus, the only practical anchorage for bamboo bars is straight bar development. Furthermore, it is not believed to be practical to produce bar end anchors for bamboo reinforcing bars.

4. As illustrated in the portal frame example, bamboo-reinforced concrete will have congested bar details. This congestion, and the variability in bamboo bars, leads to the recommendation that, in order to facilitate adequate consolidation of the concrete, bamboo bars should be placed with a spacing of at least 3 bar diameters. This limit may result in sections being larger than is strictly required to satisfy strength design considerations.

5. Like GFRP bars, bamboo bars will 'float' in concrete. This requires bars to be tied in place to resist uplift. With the larger number of bars present, this may be a cumbersome requirement.

6. In addition to through-thickness treatment for protection from insect and fungal attack, pretreatment of bamboo with special coatings to enhance bond and/or the use of waterproof membranes in ground-supported slabs are laborious and require expensive and complex application systems. This is counter to claims that bamboo-reinforced concrete is a sustainable, local and low cost alterative in developing regions.

7. Unlike steel, that when properly confined can be relied upon to contribute as 'compression reinforcement', the poor transverse properties of bamboo make it ill-suited for use in compression zones, including columns. Similarly, ACI 440.1R15 does not permit GFRP bars to contribute to compression capacity.

8. Bamboo is known to creep under the effects of sustained loads. Whereas the creep of steel reinforcement is negligible [indeed, compression steel is used to mitigate effects of concrete creep (ACI 318)], creep of bamboo is comparable to that of timber [63], limiting the sustained tensile force that can be practically resisted.

9. The behaviour of bamboo at elevated temperatures or in fire conditions is unknown. Correal [8] reports that bamboo properties degrade above $50{ }^{\circ} \mathrm{C}$. Youssefian and Rahbar [64] report the glass transition temperatures of lignin and hemicellulose (the primary components of the bamboo matrix) to range from 97 to $171{ }^{\circ} \mathrm{C}$ and 140 to $180{ }^{\circ} \mathrm{C}$, respectively. It is likely that the behaviour 
of bamboo reinforcement under fire conditions is inferior to that of steel. There is no known research on the fire performance of bamboo reinforced concrete.

\section{Life cycle assessment of bamboo and steel reinforced concrete}

Many of the studies cited in this review premise bamboo reinforcement for concrete as a "green" or "sustainable" alternative to steel reinforcement. This section attempts to quantify this claim using life cycle assessment (LCA), a well-established methodology used to assess the whole life environmental impacts and/or cost of products and services [65]. LCA has been used for the assessment of construction materials and buildings for more than 30 years and is the basis for certification methods such as Environmental Product Declaration (EPD) and Product Environmental Footprint (PEF).

With the aim of providing a benchmark for the selection of bamboo or steel as reinforcement in concrete structures and comparing their environmental impact, a LCA analysis has been carried out using the portal frame example presented and summarised in Table 1. Thus the functional unit is "a three-bay (4.3 $\mathrm{m}$ each) portal frame $(2.5 \mathrm{~m}$ tall) having a nominal superimposed gravity load capacity of $13.0 \mathrm{kN} / \mathrm{m}$. The software OpenLCA [66] was used in combination with the EcoInvent V3 database [67] and the environmental impact evaluation method IPCC2013 [68]. The data for bamboo-based construction materials and transport distances were calculated using the methods developed by Zea Escamilla and Habert [69-71]. This method allows for the generation of three scenarios combining the production efficiency of construction materials and the potential transport distances. This example was geographically located in Colombia (whose concrete design standard is equivalent to ACI 318) and this country's electricity mix was used in the lifecycle inventories. The bamboo culms are assumed to be only boric acid treated and a structural epoxy surface treatment is assumed to enhance bond. The transport of construction materials was considered to be primarily road transport. The results from the comparative LCA of bamboo- reinforced concrete and steel-reinforced concrete are presented in Fig. 4.

As shown in Fig. 4, the production of the bambooreinforced portal frame will have emissions of the order of $2000 \mathrm{kgCO}_{2}$ eq, almost twice the emissions resulting from the production of the steel-reinforced portal frame. This increase is attributed to the considerably greater amount of concrete necessary to meet the load carrying requirement of the functional unit. The increase effects both concrete materials production and transportation. The emissions savings achieved by replacing the steel-reinforcement with bamboo are surpassed by the emissions from the additional concrete. Considering only the bamboo reinforcement: the emissions contribution from the bamboo reinforcement is minimal, but the emissions from transportation of bamboo are much greater than the materials savings achieved by replacing steel; this conclusion was also drawn by Zea Escamilla and Habert [71].

\section{Summary of bamboo reinforced concrete}

Concrete reinforced with bamboo, rather than conventional steel reinforcement exhibits a different behaviour and therefore needs to be designed using different paradigms. Fundamental differences between bamboo and conventional reinforcing steel are as follows:

1. Bamboo is essentially an elastic brittle material, whereas steel exhibits considerable ductility. This limits the 'allowable' stress that may be utilised with bamboo based on the margin of safety desired.

2. The characteristic values of longitudinal tensile modulus and strength of bamboo are typically less than $10 \%$ that of steel Kaminski et al. [1, 58]. At $12 \%$ moisture content, characteristic modulus of bamboo is on the order of $7.5-13 \mathrm{GPa}$ and characteristic strength is on the order of $40 \mathrm{MPa}$ (resulting in allowable design strengths on the order of $16 \mathrm{MPa}$ ). As a result of the low modulus, serviceability considerations (i.e., deflections and crack control) are significant and typically govern design despite the low allowable strength. 
Fig. 4 LCA results with contribution to environmental impact

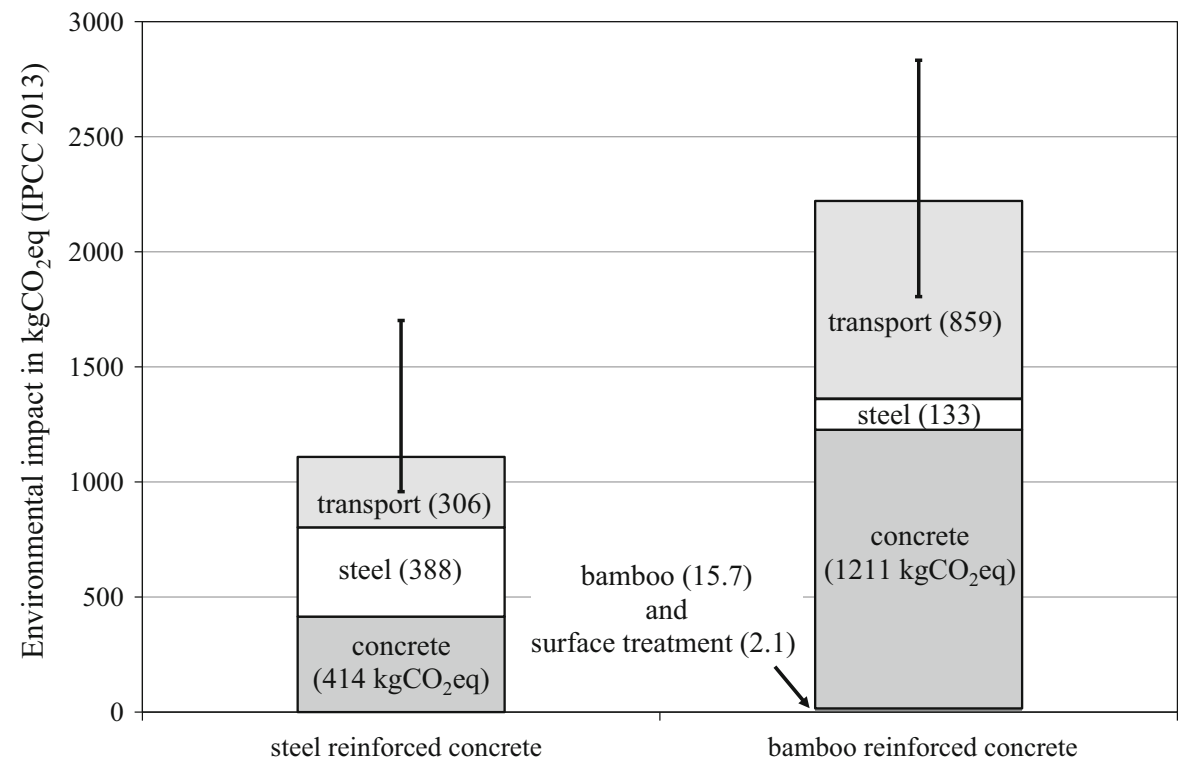

3. Bamboo is anisotropic, leading to complex interactions with the surrounding concrete, which include:

(a) The coefficient of thermal expansion of bamboo is: (a) different from that of steel and concrete, which are, themselves, similar; and (b) is almost an order of magnitude greater in the transverse direction than in the longitudinal direction affecting compatibility with the surrounding concrete, significantly impacting composite bond behaviour.

(b) Unlike steel, bamboo is dimensionally unstable and therefore needs some form of treatment to resist moisture transmission. Due to anisotropy, dimensional stability is not uniform in longitudinal and transverse directions.

4. Although not affected by corrosion, bamboo is susceptible to various degradation mechanisms associated with exposure to (a) varying hygrothermic conditions; and (b) a high-alkali environment. Both conditions are prevalent in an embedded concrete environment.

5. Bamboo is susceptible to termite and fungal attack and degrades quickly when exposed to high moisture levels. To the authors' knowledge there is no published or industry guidance that suggests that embedding timber or bamboo into concrete will protect it against rot, even if it is coated with a water-proofing product.

One of the reasons steel reinforced concrete has been such a successful material is that its ductility allows engineers to safely design statically indeterminate structures by making use of the lower bound theory of plasticity. The absence of ductility in bamboo-reinforced concrete implies that not only is it inadequate for seismically active regions, it is inappropriate for statically indeterminate structures.

Considering only the mechanics of reinforced concrete, bamboo-reinforced concrete has limited practical use. The approach of Geymayer and Cox [21] to base capacity calculation on the unreinforced capacity of the concrete and to provide $3-5 \%$ bamboo tension reinforcement appears to result in reasonable assurance of capacity beyond cracking. However, assuring bond between the bamboo and concrete by providing additional mechanical deformation and mitigating volume change of the bamboo reinforcement is critical to serviceable performance.

\section{Practical uses of bamboo as reinforcing material}

While the authors are recommending against the use of bamboo-reinforced concrete in primary structural members, certain related applications may be practical 
provided issues of durability, dimensional stability and bond between bamboo and concrete are addressed as discussed in this work.

Small cane or bamboo splints may be an alternative for crack control reinforcement for slabs on grade (slabs cast on the ground) provided at least $3 \%$ bamboo is used. Such slabs are designed to remain uncracked and/or are provided with control joints to permit only controlled cracking.

Light cement bamboo frame (LCBF) panels, known colloquially as bahareque construction, (e.g.,Gonzalez and Gutierrez [72]) are well established. LCBF construction is a modern technique utilising composite shear panels constituted of a wall matrix of bamboo or metal lath nailed onto a bamboo framing system, plastered with cement or lime mortar render. This method works well because the stresses in the wall matrix are very low. This method of construction is recognised and promoted by ISO 22156.

Small culm or bamboo splints has been proposed as reinforcement for masonry construction. Due to the role masonry reinforcement plays (as different from concrete reinforcement), some researchers consider bamboo-reinforcement as suitable to reinforce hollowcore masonry in non-seismic environments (e.g., Moroz et al. [73]).

Javadian et al. [37] have proposed the use of a heattreated, densified engineered bamboo composite for concrete reinforcement. The resulting composite strips have a reported tensile strength of $295 \mathrm{MPa}$ and a modulus of $37 \mathrm{GPa}$. To be used as concrete reinforcing bars, the composite strips are coated with epoxy resin (four variations are reported) and sand is broadcast on to this as a means of enhancing bond. Reported bond capacities ranged from 2.42 to 3.65 $\mathrm{MPa}$ in direct pull-out tests which was reported to be about $80 \%$ of comparable steel reinforcement bond strength. Such engineered bamboo composite reinforcing bars hold promise for overcoming many of the obstacles associated with using bamboo as concrete reinforcement. To the authors' knowledge no LCA or similar comparison with steel has been made to document assertions of "sustainability". Nonetheless, it is clear that the additional processing, energy and the resins used on their production will have a significant impact on environmental impact and cost.

Finally, Bamboo-fibre reinforced concrete has been proposed and demonstrated by multiple researchers including Terai and Minami [74], Ahmad et al. [75], and Brindha et al. [76]. The nature of fibre reinforcement for concrete is quite different from conventional discrete bar reinforcement and beyond the scope of this review.

\section{Conclusions}

The authors propose that bamboo reinforced concrete is an ill-considered concept. More importantly, the authors propose that bamboo reinforcement-if used safely - is not an environmentally friendly or sustainable alternative to steel. As has been shown, bambooreinforced concrete must be designed to remain uncracked; the presence of bamboo reinforcing is intended to impart a degree of ductility to the section-and may impart some post-cracking reserve capacity - in the event of an overload that results in cracking. This post-cracking behaviour is only possible if there is sufficient bond between the bamboo and concrete. It has been shown that some bond-enhancing surface treatments are sufficient to impart the bond capacity required. Nonetheless, the required 'uncracked' design increases concrete member dimensions and has a 'trickle down' effect resulting in increased formwork and foundation requirements. Additionally, the poor durability and bond characteristics of bamboo require through-thickness treatment and additional surface treatment of bamboo reinforcement, respectively. Such treatments, as described in the literature, are labour intensive, costly, and often utilise materials of known toxicity or which have handling restrictions associated with workplace health and safety. Vo and Navard [42] draw a very prescient conclusion in this regard: "A large proportion of [the methods used to overcome issues of biomass durability when embedded in concrete] are effectively helpful in easing the concrete preparation and leading to better final materials. However, most of them, if not all, have little practical value since they are either impossible to be implemented because of the use of chemicals which are not environmentally-friendly or much too expensive."

\section{Compliance with ethical standards}

Conflict of interest The authors declare that they have no conflict of interest. 
Open Access This article is distributed under the terms of the Creative Commons Attribution 4.0 International License (http:// creativecommons.org/licenses/by/4.0/), which permits unrestricted use, distribution, and reproduction in any medium, provided you give appropriate credit to the original author(s) and the source, provide a link to the Creative Commons license, and indicate if changes were made.

\section{References}

1. Kaminski S, Lawrence A, Trujillo D, King C (2016b) Structural use of bamboo Part 3: design values. Struct Eng 94(12):42-45

2. Bodig J, Jayne BA (1982) Mechanics of wood and wood composites. Van Nostrand Reinhold Company, New York

3. FPL (2010) Wood handbook-Wood as an engineering material. General Technical Report FPL-GTR-190: U.S. Department of Agriculture, Madison, WI, USA

4. Wood LW (1960) Variation of strength properties in woods used for structural purposes. Wood, Madison

5. Hebel DE, Javadian A, Heisel F, Schlesier K, Griebel D, Wielopolski M (2014) Process-controlled optimization of the tensile strength of bamboo fiber composites for structural applications. Compos B Eng 67:125-131

6. Zhou F (1981) Studies on physical and mechanical properties of bamboo wood. J Nanjing Tech Coll For Prod (2): 1-32. Cited by [77]

7. Lu X, Wang K, Yi X, Liou J, He J (1985) A study on the physic-mechanical properties of culmwood of Phyllostachys Glauca of Shandong. J Bamboo Res, Zhejiang Forestry Science Research Institute, Hangzhou, China 4(2): 98-106. Cited by [77]

8. Correal JF (2016) Bamboo design and construction. In: Harries K, Sharma B (eds) Chapter 14 in nonconventional and vernacular construction materials: characterisation, properties and applications. Woodhead (Elsevier) Publishing Series in Civil and Structural Engineering No. 58

9. Ashby MF (2011) Materials selection in mechanical design, 4th edn. Butterworth-Heinemann, Oxford

10. van der Lugt P, Voglander JG (2015) The environmental impact of industrial products-life cycle assessment and carbon sequestration. INBAR Technical Report No. 35

11. American Concrete Institute (ACI) (2015) ACI 440.1R-15 guide for the design and construction of structural concrete reinforced with fiber-reinforced polymer (FRP) Bars. American Concrete Institute (ACI), Farmington Hills

12. International Standards Organisation (ISO) (2004) ISO 22156-1 bamboo-structural design

13. Chow HK (1914) Bamboo as a material for reinforcing concrete. Massachusetts Institute of Technology. http://hdl. handle.net/1721.1/81516. Accessed 18 July 2018

14. Datta K (1936) Versuche Uber die Verwendung von Bambus im Beton bau [Experiments on the use of bamboo in concrete construction]. Der Bauingenieur (BerlinWilmersdorf) $17(1): 1$

15. De Simone D (1939) Norme, Materiali e Strutture per la Limitazione dell'impiego del Ferro nelle Construzioni. Annali dei Lavori Publlici 77(12): 1189-1223. English translation by A. Holme, Substitutes for Steel in Reinforced
Concrete. Royal Engineers Journal (Chatham-Kent), 54 (June 1940), 237-244

16. Glenn HE (1950) Bamboo reinforcement in Portland cement concrete. Engineering Experiment Station, Clemson Agricultural College, Clemson, South Carolina, Bulletin No. 4

17. Smith EF, Saucier KL (1964) Precast concrete elements with bamboo reinforcement, U. S. Army Engineer Waterways Experiment Station, Vicksburg, Mississippi. Technical Report No. 6-646

18. Hidalgo López O (1974) Bambú, su cultivo y aplicaciones en fabricación de papel, construcción, arquitectura, ingeniería, artesanía [Bamboo, its cultivation and applications in papermaking, construction, architecture, engineering, crafts]. Cali, Colombia: Estudios Técnicos Colombianos. https://searchworks.stanford.edu/view/164053. Accessed 18 July 2018

19. Brink FE, Rush PJ (1966) Bamboo reinforced concrete construction. US Naval Civil Engineering Laboratory Report, Port Hueneme

20. American Concrete Institute (ACI) (1956) ACI 318-56 Building code requirements for reinforced concrete. American Concrete Institute (ACI), Detroit

21. Geymayer HG, Cox FB (1970) Bamboo reinforced concrete. J Am Concrete Inst 67(51):841-846

22. Indra IG (1982) Bamboo as expedient reinforcement for concrete beams. M.Sc. thesis, University of Ottawa

23. Kankam JA, Ben-George M, Perry SH (1988) Bamboo-reinforced concrete beams subjected to third-point loading. ACI Struct J 85(1):61-67

24. Khare L (2005) Performance evaluation of bamboo reinforced concrete beams. M.Sc. thesis, University of Texas at Arlington

25. Rahman MM, Rashid MH, Hossain MA, Hasan MT, Hasan MK (2011) Performance evaluation of bamboo reinforced concrete beam. Int J Eng Technol 11(4):142-146

26. Subrahmanyam BV (1984) Bamboo reinforcement for cement matrices. In: New Reinforced Concrete. Surrey University Press, Guildford, England, pp 141-194

27. Youssef MAR (1976) Bamboo as a substitute for steel reinforcement in structural concrete. New Horiz Constr Mater 1:525-554

28. Ghavami K (1995) Ultimate load behaviour of bambooreinforced lightweight concrete beams. Cement Concr Compos 17:281-288

29. Ghavami K (2005) Bamboo as reinforcement in structural concrete elements. Cement Concr Compos 27:637-649

30. Agarwal A, Nanda B, Maity D (2014) Experimental investigation on chemically treated bamboo reinforced concrete beams and columns. Constr Build Mater 71:610-617

31. Sevalia JK, Siddhpura NB, Agarwal CS, Shah DP, Kapadia JV (2013) Study on bamboo as reinforcement in cement concrete. Int J Eng Res Appl 3(2):1181-1190

32. Terai M, Minami K (2012a) Research and development on bamboo reinforced concrete structure. In: 15 th World conference on earthquake engineering, Lisbon

33. Terai M, Minami K (2011) Fracture behavior and mechanical properties of bamboo reinforced concrete members. Eng Proc 10:2967-2972 
34. Leelatanon S, Srivaro S, Matan N (2010) Compressive strength and ductility of short concrete columns reinforced by bamboo. Songklanakarin J Sci Technol 32(4):419-424

35. Sakaray H, Togati NVVK, Reddy IVR (2012) Investigation on Properties of Bamboo as Reinforcing Material in Concrete. Int J Eng Res Appl 2(1):77-83

36. Archila HF, Pesce H, Ansell M, Ball R (2015) Limeboo: lime as replacement of cement in wall-framing systems with bamboo-guadua (bahareque encementado). Tenth World Bamboo Congress, Damyang

37. Javadian A, Wielopolski M, Smith FC, Hebel DE (2016) Bond-behavior study of newly developed bamboo-composite reinforcement in concrete. Constr Build Mater 122:110-117

38. Ho M, Wang H, Lee J-H, Ho C-K, Lau K-T, Leng J, Hui D (2012) Critical factors on manufacturing processes of natural fibre composites. Compos B Eng 43(8):3549-3562

39. Li XB, Shupe TF, Peter GF, Hse CY, Eberhardt TL (2007) Chemical changes with maturation of the bamboo species Phyllostachys pubescens. Trop For Sci 19(1):6-12

40. Hisham HN, Othman S, Rokiah H, Latif MA, Ani S, Tamizi MM (2006) Characterization of bamboo Gigantochloa scortechinii at different ages. Trop For Sci 18(4):236-242

41. Gram H (1983) Durability of natural fibres in concrete. Swedish Cement and Concrete Research Institute, Stockolm. http://www.cbi.se/objfiles/1/HansErikGramavh_1704081873.pdf. Accessed 18 July 2018

42. Vo LTT, Navard P (2016) Treatments of plant biomass for cementitious building materials_a review. Constr Build Mater 121:161-176

43. Pacheco-Torgal F, Jalali S (2011) Cementitious building materials reinforced with vegetable fibres: a review. Constr Build Mater 25:575-581

44. Behnood A, Van Tittelboom K, De Belie N (2016) Methods for measuring $\mathrm{pH}$ in concrete: a review. Constr Build Mater 105:176-188

45. Pickering KL, Efendy MGA, Le TM (2016) A review of recent developments in natural fibre composites and their mechanical performance. Compos A Appl Sci Manuf $83: 98-112$

46. Hosoda K (1942) Bamboo reinforced concrete. In: Syukyosya Syoin, Japan

47. Kriker A, Bali A, Debicki G, Bouziane M, Chabannet M (2008) Durability of date palm fibres and their use as reinforcement in hot dry climates. Cement Concr Compos 30:639-648

48. Ramakrishna G, Sundararajan T (2005) Studies on the durability of natural fibres and the effect of corroded fibres on the strength of mortar. Cement Concr Compos 27:575-582

49. Roma L, Martello L, Savastano H (2008) Evaluation of mechanical, physical and thermal performance of cementbased tiles reinforced with vegetable fibers. Constr Build Mater 22:668-674

50. Toledo Filho R, Scrivener K, England G, Ghavami K (2000) Durability of alkali-sensitive sisal and coconuts fibres in cement mortar composites. Cement Concr Compos 22:127-143

51. John V, Cincotto M, Sjotrom C, Agopyan V, Oliveira C (2005) Durability of slag mortar reinforced with coconut fibre. Cement Concr Compos 27:565-574
52. Tonoli G, Santos S, Joaquim A, Savastano H (2010) Effect of accelerated carbonation on cementitious roofing tiles reinforced with lignocellulosic fibre. Constr Build Mater 24:193-201

53. Jorge FC, Pereira C, Ferreira JMF (2004) Wood-cement composites: a review. Holz Roh Werkst 62:370-377

54. Janssen J (2000) Designing and building with bamboo. In: INBAR Technical Report 20, INBAR, Beijing, China

55. Liese W, Tang TKH (2015) Preservation and drying of bamboo. In: Liese W, Köhl M (eds) Bamboo. The plant and its uses, vol 10. Springer, Berlin, pp 257-297

56. Wood Protection Association (2012) Manual: industrial wood preservation-specification and practice, 2nd edn. Wood Protection Association Castleford, Castleford

57. University of Tennessee Agricultural Extension Service (2001) Subterranean Termite Control, PB1344-3M-4/01. http://trace.tennessee.edu/utk_agexdise/15/. Accessed Nov 2017

58. Kaminski S, Lawrence A, Trujillo D, King C (2016a) Structural use of bamboo. Part 2: durability and preservation. Struct Eng 94(10):38-43

59. Ridout B (1999) Timber decay in buildings: the conservation approach to treatment. E. \& F.N. Spon, Abingdon

60. Martys N, Ferraris C (1997) Capillary transport in mortars and concrete. Cem Concr Res 27(5):747-760

61. Liese W, Kumar S (2003) INBAR Technical Report 22: bamboo preservation compendium. INBAR, Beijing

62. American Concrete Institute (ACI) (2014) ACI 318-14 Building code requirements for structural concrete. American Concrete Institute (ACI), Farmington Hills

63. Gottron J, Harries K, Xu Q (2014) Creep behaviour of bamboo. J Constr Build Mater 66:79-88

64. Youssefian S, Rahbar N (2015) molecular origin of strength and stiffness in bamboo fibrils. Nat/Sci Rep. https://doi.org/ 10.1038/srep11116

65. Hellweg S, Canals LM (2014) Emerging approaches, challenges and opportunities in life cycle assessment. Science 344(6188):1109-1113

66. Green Delta (2017) OpenLCA—-the open source life cycle and sustainability assessment Software. http://www. openlca.org/. Accessed 18 July 2018

67. SCLCI (2017) EcoInvent Database v3. Swiss Centre for Life Cycle Inventories. http://www.ecoinvent.org. Accessed 18 July 2018

68. Edenhofer O, Pichs-Madruga R, Sokona Y, Farahani E, Kadner S, Seyboth K (2014) Climate Change 2014: mitigation of climate change. In: Contribution of Working Group III to the Fifth Assessment Report of the Intergovernmental Panel on Climate Change (IPCC 2014), Cambridge, UK and New York, NY, USA

69. Zea Escamilla E, Habert G (2016) Method and application of characterisation of life cycle impact data of construction materials using geographic information systems. Int J Life Cycle Assess 22:1-10

70. Zea Escamilla E, Habert G (2015) Regionalizing the environmental impact of bamboo-based buildings by integrating life cycle assessment with geographic information systems. A comparative case-study in Colombia. World Bamboo Congress, Damyang

71. Zea Escamilla E, Habert G (2013) Environmental impacts from the production of bamboo based construction materials 
representing the global production diversity. J Clean Prod 66:117-127

72. Gonzalez G, Gutierrez J (2005) Structural performance of bamboo 'bahareque' walls under cyclic load. J Bamboo Rattan 4(4):353-368

73. Moroz JG, Lissel SL, Hagel MD (2014) Performance of bamboo reinforced concrete masonry shear walls. Constr Build Mater 61:125-137

74. Terai M, Minami K (2012b) Basic study on mechanical properties of bamboo fiber reinforced concrete. In: IABSE 2012, Cairo
75. Ahmad S, Raze A, Gupta H (2014) Mechanical properties of bamboo fibre reinforced concrete. In: 2nd international conference on research in science, engineering and technology, Dubai, 21-22 March 2014

76. Brindha M, Khan S, Narayanan SS, Kumar AMS, Viviek V (2017) Properties of concrete reinforced with bamboo fibre. Int J Innov Res Sci Eng Technol 6(3):3809-3812

77. Janssen J (1991) Mechanical properties of bamboo. Kluwer Academic Publishers, Dordecht 